\title{
Research
}

\section{Local People, Nature Conservation, and Tourism in Northeastern Finland}

\author{
$\underline{\text { Anne Törn }}^{1}, \underline{\text { Pirkko Siikamäki }}^{1}, \underline{\text { Anne Tolvanen }}^{2}, \underline{\text { Pekka Kauppila }}^{1}$, and Jussi Rämet ${ }^{1}$
}

\begin{abstract}
The opinions and perceptions of local communities are central issues in the sustainable management of conservation areas. During 2002 and 2003, we studied the opinions of local people about nature conservation and the development of tourism to investigate whether these opinions were influenced by socioeconomic and demographic factors. Data were collected via a survey of local residents in six areas with different histories of land use, land ownership, conservation, and tourism development. We classified respondents by cluster analysis into three different groups according to their opinions about nature conservation and tourism development: (1) sympathetic to nature conservation, but quite neutral to tourism development $(57.7 \%)$; (2) critical of nature conservation, but quite neutral to tourism development (30.5\%); and (3) quite neutral to nature conservation, but critical of tourism development (11.8\%). The most important factors for classification were residential area, age, level of education, primary occupation, indigenousness, frequency of contact with tourists through work, and effects of nature conservation on household economy. On the other hand, gender, level of income, land ownership, land donation for conservation, and income from tourism did not affect opinions concerning nature conservation and tourism development. Almost equal proportions of residents living in close proximity to conservation areas in Kuusamo had positive and negative opinions about nature conservation. Residents living in close proximity to conservation areas regarded conservation as something that might reduce employment and incomes. On the other hand, a greater proportion of residents living near tourist resorts and farther from conservation areas had positive opinions about and perceptions of nature conservation and tourism development. Based on the proportional division of all respondents into the three groups, there may be a coexistent relationship between nature conservation and tourism in our study area. When local stakeholders had a chance to commit to the planning process, they had positive perceptions of and opinions about nature conservation and tourism development in their residential areas. As a result, we concluded that negative opinions and a lack of commitment to the planning process may hinder local development.
\end{abstract}

Key Words: opinions; residents; nature conservation; tourism; Finland; survey; socioeconomic factors

\section{INTRODUCTION}

In addition to their principal function of protecting natural environments, national parks and protected areas generally have the crucial tasks of promoting education, recreation, tourism, and the economic wealth of local communities. When carefully planned and effectively managed, tourism can provide significant benefits to protected areas and nearby communities (Eagles et al. 2002), especially to rural communities in developing countries that are strongly dependent on natural resources (Tosun 1999, 2000). Even though there are many definitions and even many traditions when it comes to characterizing sustainable tourism (Saarinen
2006), the sustainable use of environmental resources for tourism is emphasized when protected areas are used as tourist destinations. For instance, according to recent guidelines from UNEP, sustainable tourism should maintain essential ecological processes and help to conserve natural heritage and biodiversity, respect the socio-cultural authenticity of host communities, and provide socioeconomic benefits to all stakeholders (UNEP 2007).

Because of the rapid decline in the importance of agriculture and forestry in rural and peripheral areas, the development of tourism has been considered as an alternative for enhancing economic wealth in 
northern Europe (e.g., Parks et al. 2002). In Finland, traditional livelihoods, nature conservation, and tourism have a long and a partly shared history (Saastamoinen et al. 2002). Conflicts involving nature conservation, tourism, and traditional forms of land use, e.g., reindeer herding (Helle and Särkelä 1993, Sekhar 2003), have arisen with increasing numbers of tourists (Forbes et al. 2004).

Western and Wright (1994) considered that the basis for conservation development is the opinions of local communities about nature conservation. Conventionally, research on opinions about tourism has focused on the interactions of local residents with tourism and its development (Murphy 1985, Shortt 1994, Pearce et al. 1996). There are only a few studies that investigated the opinions of local residents with regard to both nature conservation and tourism development, and most of them were conducted in developing countries (e.g., Fiallo and Jacobson 1995, Trakolis 2001, Sekhar 2003, Tosun 1999, 2000, 2006). Even though the citizens of developed countries might have had more input than their counterparts in the developing countries into the management of conservation areas and of nature-based tourism that features conservation areas as tourist destinations, there has been virtually no research conducted on this subject.

According to Budowski (1976), the relationship between nature conservation and tourism can be classified into three categories: coexistence, conflict, and symbiosis. Coexistence implies that the views of operators in nature conservation and tourism are divergent and their interactions unsubstantial. Coexistence may transform either into conflict or into symbiosis. Conflict arises in a situation in which tourism has detrimental effects on the environment or there is little interaction between tourism and conservation. Symbiosis is a complex relationship whereby the protection of the environment can be enhanced by tourism because of the advantages of interactions between conservationists and the tourism industry.

In this study, we widened Budowski's (1976) livelihood-oriented framework to include local communities by focusing on the opinions of local residents about nature conservation and naturebased tourism. According to the most commonly used definition, nature-based tourism or ecotourism is traveling in relatively undisturbed areas to visit specific natural attractions and resources (Boo 1990, Ecotourism Society 1993). Moreover,
Buckley's (1994) definition of ecotourism combines tourism with natural resources, sustainable management, conservation, and the concept of environmental education. Because almost the whole tourism industry in our study area is based on natural resources and attractions (Hunter and Green 1995, Vuoristo and Vesterinen 2001, Vuoristo 2002), we use just the term "tourism" when discussing nature-based tourism. We first created a schematic model that classifies the residents based on their perceptions of and opinions about nature conservation and tourism development (Fig. 1). Using this schematic model as a framework, our second step was to conduct a survey of local residents in northeastern Finland to determine their opinions about nature conservation and tourism development. The local communities included in the survey had contrasting histories of land use, land ownership, conservation, and tourism development. Third, we investigated whether their opinions were dependent on socioeconomic and demographic factors. We expected that the resulting grouping of local residents into opinion groups would reflect the potential for the socioeconomic sustainability of nature conservation and tourism development and how these activities had fared in the residential areas of the respondents. Finally, we discuss how socioeconomic sustainability may depend on the level of involvement of local stakeholders in the process of conservation and tourism.

\section{METHODS}

\section{Study areas}

The research was carried out in the municipalities of Kuusamo and Pudasjärvi in northeastern Finland (Fig. 2). Kuusamo is sparsely populated, with 17,394 inhabitants and 3.0 persons $/ \mathrm{km}^{2}$ (Statistics Finland 2004). There are three types of forest ownership in Kuusamo: communally owned forests, private land, and state-owned land. The nature conservation areas cover $\sim 10 \%$ of the land cover in Kuusamo. At present, Kuusamo is one of the most attractive tourism destinations in Finland (Finnish Tourist Board 2005). Ruka, which is located in the middle of Kuusamo, is among the most popular ski resorts in the country (Vuoristo and Vesterinen 2001). Tourism in Ruka is mostly concentrated in the winter season. The oldest and most important conservation area for tourism and recreation included in this study is Oulanka National 
Fig. 1. Schematic model of the opinions of residents about nature conservation and tourism development.

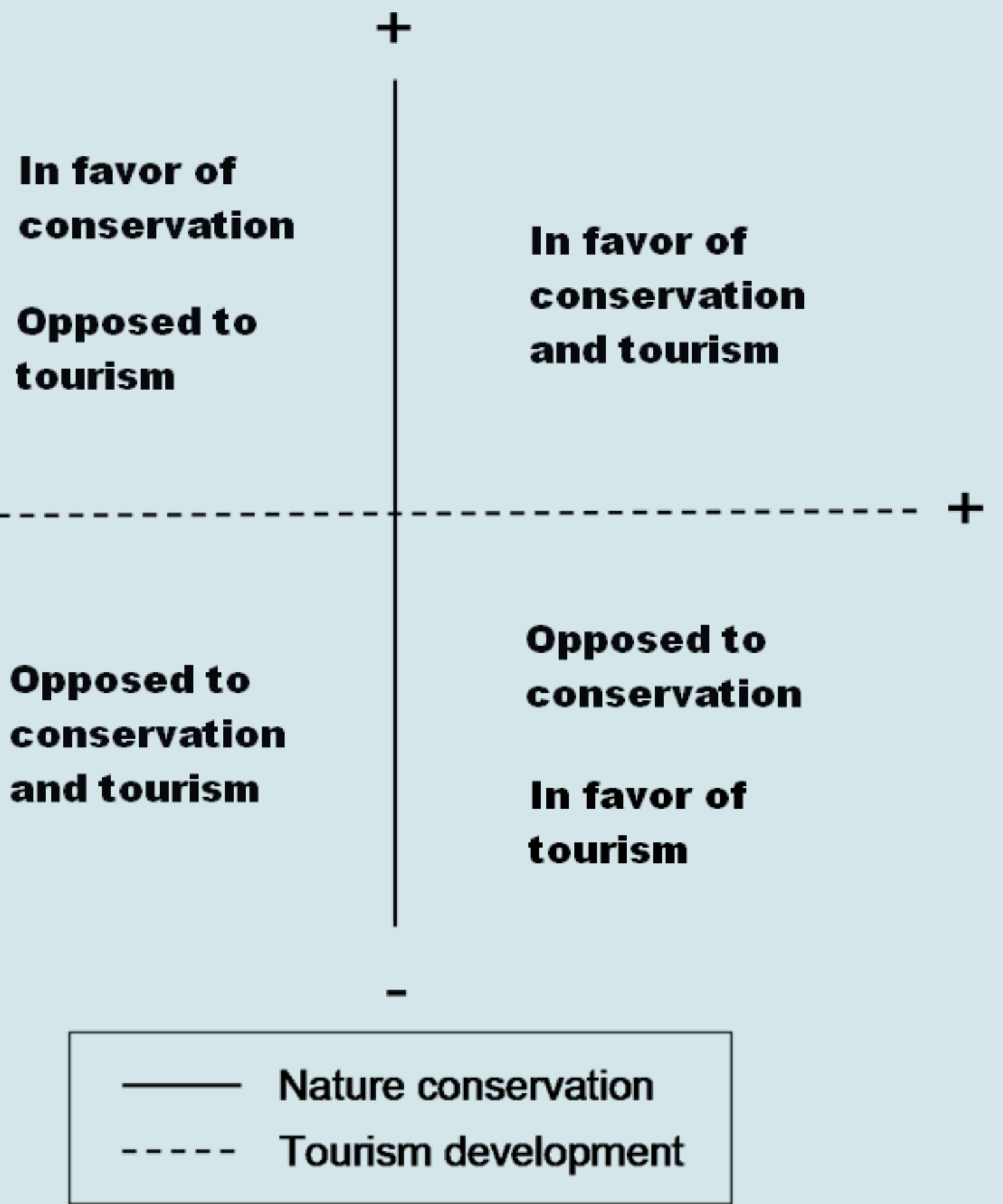


Park; established in 1956 in northern Kuusamo, it includes some of the neighboring municipality of Salla. Recently, conservation areas of old-growth forests were also established in southern Kuusamo after a long and difficult process in which there were many conflicts among conservationists, local administrators, and forest owners. Small-scale tourism is now developing in southern Kuusamo.

Pudasjärvi is even less populated than Kuusamo, with 9674 inhabitants and 1.6 inhabitants $/ \mathrm{km}^{2}$ (Statistics Finland 2004). Forest ownership is divided between state-owned and private land. Conservation acts have mainly concentrated on state-owned areas (Aarnio 2001). Syöte National Park was established in Pudasjärvi in 2000. In addition to nature, the main tourist attraction in the area of Syöte National Park is the well-developed neighboring ski resort of Syöte (Vuoristo and Vesterinen 2001).

\section{Survey}

We collected data via a mail survey of local residents in four areas in Kuusamo and two areas in Pudasjärvi in November 2002 and May 2003, respectively. The areas included: (1) the tourist resort at Ruka; (2) the tourist resort at Syötekylä; the areas neighboring the conservation areas in (3) northern Kuusamo, (4) southern Kuusamo, and (5) Sarajärvi; and (6) downtown Kuusamo (Fig. 2). The characteristics of the study areas are summarized in Table 1. Random sampling was based on regional postal codes and village land registers. In Kuusamo town, northern Kuusamo, and southern Kuusamo, the questionnaire was sent to 200 households in each area, whereas in Ruka, Syötekylä, and Sarajärvi, it was sent to every household. The surveyed population included local people more than 18 years old. Of the total of 929 questionnaires sent to households, 296 responses (31.9\%) were returned (Appendix 1). With regard to area, the response rate was $33.3 \%$ in Ruka, $32.5 \%$ in downtown Kuusamo, $31.5 \%$ in northern Kuusamo and southern Kuusamo, 32.7\% in Syötekylä, and $29.4 \%$ in Sarajärvi. No reminders were sent.

The socioeconomic and demographic variables measured were residential area, level of education, primary occupation, level of income, indigenousness, gender, age, land donation for conservation program, land ownership, income from tourism, frequency of contact with tourists through work, and the effects of nature conservation on household economy. Details of the results are shown in Appendix 1.

\section{Statistical analysis}

We used factor analysis to reduce the 17 statements into smaller sets of underlying factors. This helped to detect the presence of meaningful patterns among the original variables and to extract the main opinion factors. We analyzed answers to the statements related to nature conservation and tourism development by using principal component analysis (PCA) with varimax orthogonal rotation on 17 statements measured by using the five-point Likert scale: (1) strongly disagree, (2) disagree, (3) neutral, (4) agree, and (5) strongly agree. We used two factors having an Eigenvalue of more than 1 in our analysis. PCA was used to identify key dimensions. The data were appropriate for analysis according to the Kaiser-Meyer-Olkin measure of sampling adequacy value of 0.916 (Hair et al 1995). The Bartlett Test of Spherity was significant $\left(\chi^{2}=\right.$ $2417.421, p<0.001)$, indicating that correlations existed among the statements. Two components were found that were rotated into interpretable factors (Table 2). The two key dimensions identified approximately $57 \%$ of the total variance. In the interpretation of the dimensions, only variables with a factor loading greater than 0.40 were extracted (Kim and Muller 1978, Hair et al. 1995). According to correlations between factor loadings and statements, the first PCA axis represented questions related to nature conservation and the second questions related to tourism development (Table 2). Factor 1, a nature conservation dimension, consisted of eight statements, and factor 2, a tourism development dimension, comprised nine statements (Table 2). Factor 1 accounted for $43.2 \%$ of total variance, and factor 2 accounted for $14.2 \%$ of total variance.

We used hierarchical cluster analysis and squared Euclidean methods to classify respondents into groups based on PCA results or factor scores (Fig. 3 ). We formed clusters based on factor scores that had a mean of zero and standard deviation of 1 . A solution of three clusters was chosen within solutions of two to six clusters. This gave a better predictive ability than the other cluster solutions and was easier to interpret than solutions with a higher number of clusters. Also, higher sample sizes of three clusters ensured a better power to statistical 
Fig. 2. Study areas: (1) the Ruka tourist resort; (2) the Syötekylä tourist resort; (3) northern Kuusamo, which is near a conservation area; (4) southern Kuusamo, which is near a conservation area; (5) Sarajärvi, which is near a conservation area; and (6) downtown Kuusamo.

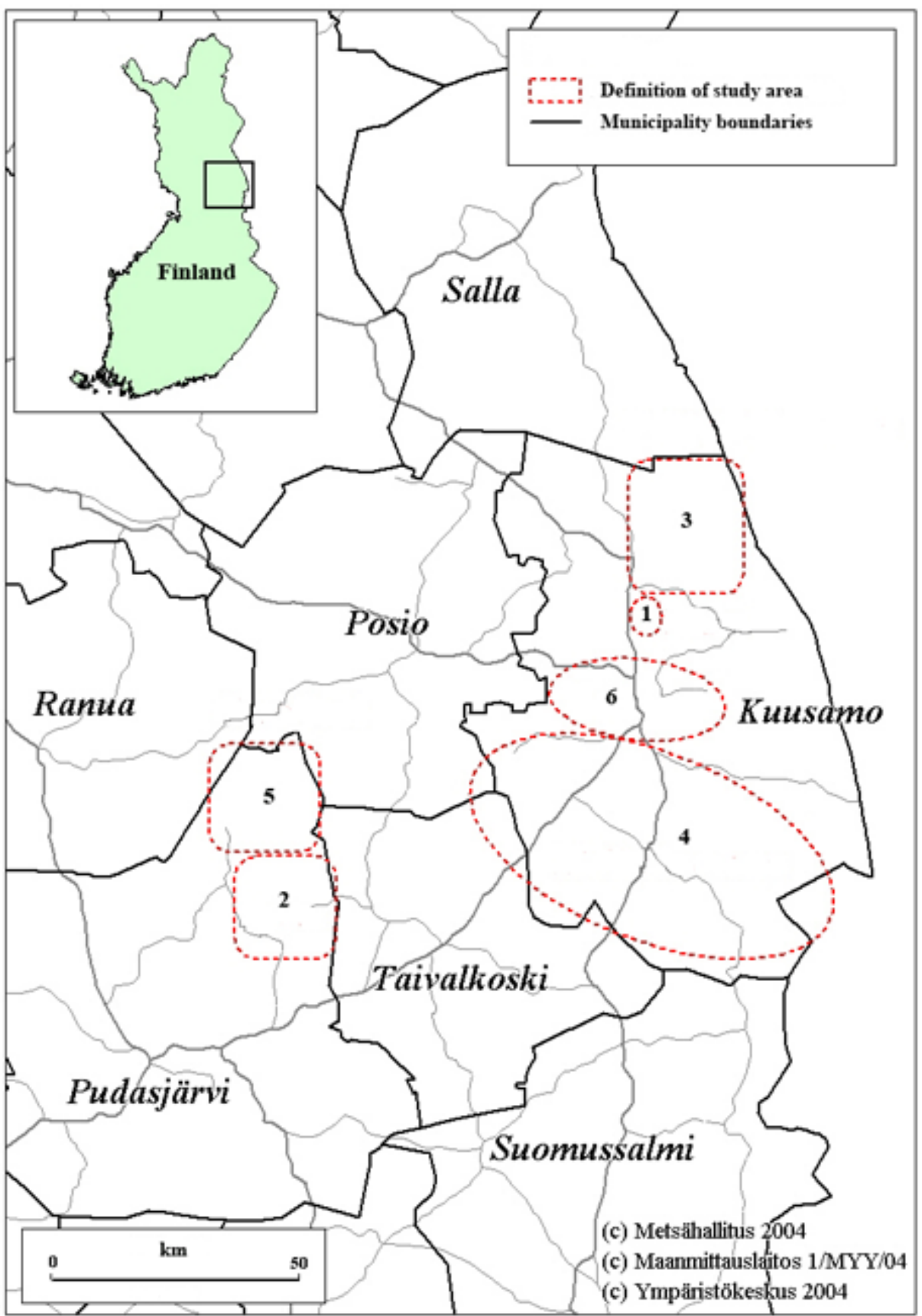


Table 1. Description of residential area of respondents. Year represents the year that nature conservation was first established in the area.

\begin{tabular}{|c|c|c|c|c|c|c|}
\hline $\begin{array}{l}\text { Study a- } \\
\text { rea }\end{array}$ & $\begin{array}{l}\text { Geographic } \\
\text { location }\end{array}$ & Municipality & Conservation area & Year & $\begin{array}{l}\text { Size of the } \\
\text { conservation } \\
\text { area }\end{array}$ & Tourists/yr \\
\hline $\begin{array}{l}\text { Northern } \\
\text { Kuusamo }\end{array}$ & $66^{\circ} 17^{\prime} 29^{\circ} 22^{\prime}$ & Kuusamo & $\begin{array}{l}\text { Oulanka National } \\
\text { Park }\end{array}$ & $\begin{array}{l}\text { 1956, extended } \\
1982 \text { and } 1989\end{array}$ & $277 \mathrm{~km}^{2}$ & $\begin{array}{l}\text { 173,000 (Metsähallitus } \\
\text { 2006) }\end{array}$ \\
\hline $\begin{array}{l}\text { Southern } \\
\text { Kuusamo }\end{array}$ & $65^{\circ} 36^{\prime} 29^{\circ} 33^{\prime}$ & Kuusamo & $\begin{array}{l}\text { Network of } \\
\text { conservation areas }\end{array}$ & 1998 & $200 \mathrm{~km}^{2}$ & $\begin{array}{l}\text { 17,000 (M. } \\
\text { Tapaninen, personal } \\
\text { communication) }\end{array}$ \\
\hline Sarajärvi & $65^{\circ} 43^{\prime} 27^{\circ} 30^{\prime}$ & $\begin{array}{l}\text { Pudasjärvi (Taiva- } \\
\text { lkoski, Posio) }\end{array}$ & Syöte National Park & 2000 & $299 \mathrm{~km}^{2}$ & $\begin{array}{l}\text { 34,000 (Metsähallitus } \\
\text { 2006) }\end{array}$ \\
\hline Ruka & $66^{\circ} 07^{\prime} 29^{\circ} 13^{\prime}$ & Kuusamo & $\ldots$ & $\ldots$ & $\ldots$ & $\begin{array}{l}350,000 \text { (Finnish } \\
\text { Tourist Board 2005) }\end{array}$ \\
\hline Syötekylä & $65^{\circ} 31^{\prime} 27^{\circ} 58^{\prime}$ & Pudasjärvi & $\ldots$ & $\ldots$ & $\ldots$ & $\begin{array}{l}31,000 \text { (Finnish } \\
\text { Tourist Board 2005) }\end{array}$ \\
\hline $\begin{array}{l}\text { Downto- } \\
\text { wn Kuu- } \\
\text { samo }\end{array}$ & $65^{\circ} 56^{\prime} 29^{\circ} 15^{\prime}$ & Kuusamo & $\ldots$ & $\ldots$ & $\ldots$ & $\ldots$ \\
\hline
\end{tabular}

tests than the solutions with higher numbers of clusters. We conducted $\chi^{2}$ tests to investigate if cluster membership was dependent on the socioeconomic and demographic variables of the respondents. We performed statistical analyses with SPSS 12 for Windows (SPS 2003).

\section{RESULTS}

\section{Respondents in different residential areas}

Table 3 represents the characteristics of respondents in different residential areas. The inhabitants of the communities close to conservation areas were on average older than those living near tourism areas and in downtown Kuusamo. More than half of the respondents in all conservation areas had an elementary school education, whereas in other residential areas a greater proportion of the respondents had a higher level of education.
Approximately half of the respondents in all the conservation areas were pensioners, whereas in other residential areas a larger proportion of the population were employees. With the exception of Sarajärvi, where more than half of the residents were at the lowest income level, most respondents had incomes at the intermediate level. More than half of the respondents in the communities close to the conservation areas were native to the area, whereas approximately half of the respondents in tourism areas were either returnees or newcomers. The majority of the respondents in northern Kuusamo and southern Kuusamo owned land, and a quarter of them had donated land for conservation. Approximately half of the respondents in tourism areas and downtown Kuusamo owned land, but only a few had donated land for conservation. Of the respondents living near conservation areas, $48-82 \%$ had no contact with tourists through their work and 73-91\% did not receive income from tourism, whereas the majority of the respondents living close to tourism areas had contact with tourists through 
Table 2. Spearman correlation coefficients between statements using classification of opinions about nature conservation and tourism development based on the 17 statements $(n=246-264)$. Statements marked in boldface print were used to create factor variables $(>0.40)$.

\begin{tabular}{|c|c|c|c|}
\hline Statement & Communalities & $\begin{array}{l}\text { Nature cons- } \\
\text { ervation }^{\dagger}\end{array}$ & $\begin{array}{l}\text { Tourism deve- } \\
\text { lopment }^{\ddagger}\end{array}$ \\
\hline There are too many conservation areas in the region. & 0.68 & 0.81 & 0.12 \\
\hline The establishment of conservation areas is important. & 0.64 & 0.79 & 0.15 \\
\hline $\begin{array}{l}\text { The establishment of the conservation areas decreases employment within } \\
\text { the region. }\end{array}$ & 0.58 & 0.76 & 0.05 \\
\hline $\begin{array}{l}\text { By establishing conservation areas, appreciation of the home district has } \\
\text { increased. }\end{array}$ & 0.74 & 0.82 & 0.24 \\
\hline $\begin{array}{l}\text { Increasing nature conservation areas has improved famliarity with nature in } \\
\text { the home district. }\end{array}$ & 0.62 & 0.76 & 0.22 \\
\hline Landowners should donate valuable areas to conservation for compensation. & 0.47 & 0.66 & 0.16 \\
\hline $\begin{array}{l}\text { The existence of nature conservation areas is important to me, although I do } \\
\text { not visit them. }\end{array}$ & 0.65 & 0.75 & 0.30 \\
\hline The area's forests are appealing to tourists. & 0.51 & 0.53 & 0.47 \\
\hline The region succeeds because of tourism. & 0.50 & 0.14 & 0.70 \\
\hline Tourism in my residential area is a positive proposition. & 0.59 & 0.21 & 0.74 \\
\hline Income from tourism will stay in the region. & 0.54 & 0.05 & 0.73 \\
\hline Tourism development can compensate for jobs lost to forest conservation. & 0.59 & 0.52 & 0.57 \\
\hline $\begin{array}{l}\text { The municipality has taken local people into account in tourism } \\
\text { development. }\end{array}$ & 0.55 & 0.16 & 0.73 \\
\hline Companies have taken local people into account in tourism development. & 0.50 & 0.20 & 0.68 \\
\hline Visitors to the area are well behaved. & 0.47 & 0.08 & 0.68 \\
\hline The economic benefits of tourism are greater than the disadvantages. & 0.58 & 0.28 & 0.71 \\
\hline Tourism development is important for the future. & 0.55 & 0.25 & 0.70 \\
\hline
\end{tabular}

${ }^{\dagger}$ Contribution to variance: $43.2 \%$

Contribution to variance: $14.2 \%$ 
Fig. 3. Biplot of the hierarchical cluster analysis. Midpoints present arithmetic means calculated from individual observations. Standard errors are seldom visible because of low values.

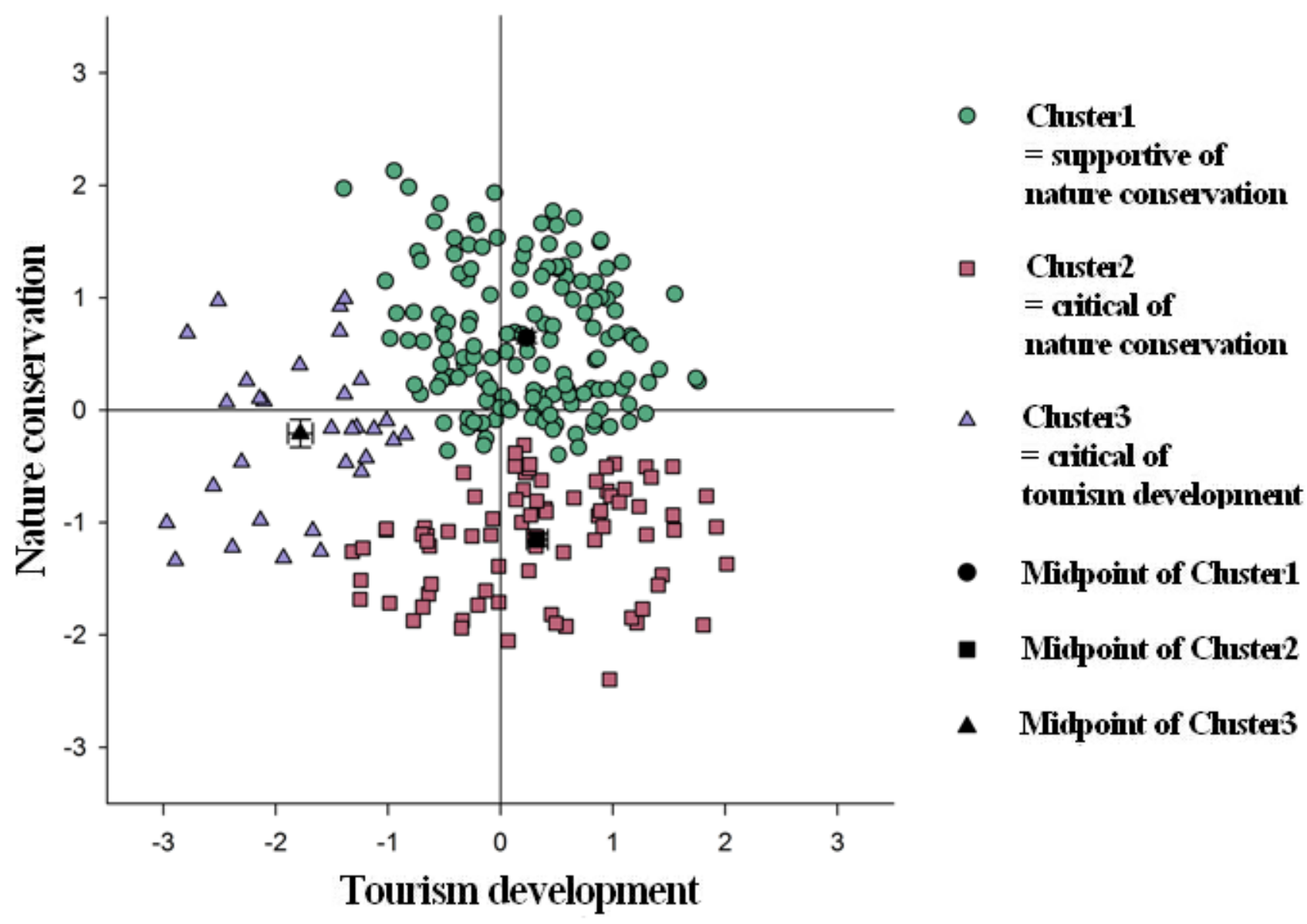

work, and $67 \%$ and $33 \%$ of the respondents in Ruka and Syötekylä, respectively, received income from tourism. In every study area, the majority of respondents reported that nature conservation had no effect on household economy.

\section{Opinions about nature conservation and tourism development}

Our cluster analysis classified the respondents into three categories according to the opinions about nature conservation and tourism development they expressed in individual observations (Fig. 3). Based on their opinions, respondents were assigned to one of three clusters: (1) supportive of nature conservation but neutral to tourism development, (2) critical of nature conservation but neutral to tourism development, and (3) critical of tourism development but neutral to nature conservation (Fig. 3). Opinions about nature conservation and tourism development depended on residential area, age group, level of education, primary occupation, indigenousness, frequency of contact with tourists through work, and the effects of nature conservation on household economy (Table 4).

\section{Cluster1: Supportive of nature conservation}

Cluster1 members had, on average, positive opinions about nature conservation. The observations 
Table 3. Percentages of respondents with particular socioeconomic and demographic characteristics in different residential areas: Ruka, Syötekylä, northern Kuusamo, southern Kuusamo, Sarajärvi, and downtown Kuusamo.

\begin{tabular}{lllllll}
\hline \hline Socioeconomic/demographic characteristic Ruka & Syötekylä & $\begin{array}{l}\text { Northern K- Southern K- Sarajärvi } \\
\text { uusamo } \\
\text { uusamo }\end{array}$ & $\begin{array}{l}\text { Downt } \\
\text { Kuusa }\end{array}$ \\
\hline Age & & & & & & \\
$20-44 \mathrm{yr}$ & $52.0 \%$ & $20.6 \%$ & $29.1 \%$ & $17.5 \%$ & $4.5 \%$ & $36.5 \%$ \\
$45-64 \mathrm{yr}$ & $32.0 \%$ & $50.0 \%$ & $43.5 \%$ & $46.0 \%$ & $59.1 \%$ & $36.5 \%$ \\
$65-90 \mathrm{yr}$ & $16.0 \%$ & $29.4 \%$ & $27.4 \%$ & $36.5 \%$ & $36.4 \%$ & $27.0 \%$
\end{tabular}

Level of education

Higher education

High school

Elementary school

Primary occupation

Entrepreneur

Employee

Pensioner

Other

Gross annual household earnings in Euros (average 15,504 Euros)

Less than 15,000-45,000

45,000-75,000

More than 75,000

Indigenousness

Native

Returnee

Newcomer

Land ownership

$\begin{array}{llllll}28.0 \% & 17.6 \% & 21.3 \% & 19.1 \% & 15.9 \% & 7.7 \% \\ 44.0 \% & 35.3 \% & 26.2 \% & 23.8 \% & 15.9 \% & 52.3 \% \\ 16.0 \% & 35.3 \% & 41.0 \% & 49.2 \% & 50.0 \% & 30.8 \% \\ 12.0 \% & 11.8 \% & 11.5 \% & 7.9 \% & 18.2 \% & 9.2 \%\end{array}$

$\begin{array}{llllll}36.0 \% & 18.8 \% & 16.7 \% & 16.4 \% & 9.3 \% & 40.6 \% \\ 40.0 \% & 43.7 \% & 16.7 \% & 24.6 \% & 37.2 \% & 25.0 \% \\ 24.0 \% & 37.5 \% & 66.6 \% & 59.0 \% & 53.5 \% & 34.4 \%\end{array}$

$\begin{array}{llllll}8.6 \% & 41.2 \% & 34.0 \% & 33.4 \% & 63.9 \% & 25.4 \% \\ 69.8 \% & 47.1 \% & 49.0 \% & 58.3 \% & 22.2 \% & 52.4 \% \\ 21.6 \% & 11.8 \% & 17.0 \% & 8.3 \% & 13.9 \% & 22.2 \%\end{array}$

$\begin{array}{llllll}41.7 \% & 35.3 \% & 55.6 \% & 51.6 \% & 61.4 \% & 39.1 \% \\ 8.3 \% & 47.1 \% & 25.4 \% & 32.3 \% & 13.6 \% & 23.4 \% \\ 50.0 \% & 17.6 \% & 19.0 \% & 16.1 \% & 25.0 \% & 37.5 \%\end{array}$




\begin{tabular}{lllllll}
\hline Own land & $50.0 \%$ & $58.8 \%$ & $77.6 \%$ & $96.4 \%$ & $23.3 \%$ & $46.7 \%$ \\
Do not own land & $50.0 \%$ & $41.2 \%$ & $22.4 \%$ & $3.6 \%$ & $76.7 \%$ & $53.3 \%$
\end{tabular}

Donated land to nature conservation program

Donated land

Did not donate land

Income from tourism

Main income from tourism

Occasional income from tourism

No income from tourism

Contact with tourists through work

Frequent

Infrequent

Not at all

Effects of nature conservation on household economy

Disadvantage

No effect

Benefit

$\begin{array}{ll}56.6 \% & 29.0 \% \\ 21.7 \% & 35.5 \% \\ 21.7 \% & 35.5 \%\end{array}$

$13.5 \%$

$39.0 \%$

$47.5 \%$

$6.3 \%$

$20.6 \%$

$73.0 \%$

$3.2 \%$

$12.7 \%$

$84.1 \%$

$2.3 \%$

$4.6 \%$

$6.8 \%$

$10.8 \%$

$33.3 \% \quad 66.7 \%$

$21.7 \% \quad 35.5 \%$

$47.5 \%$

$61.7 \%$

$\begin{array}{lll}11.7 \% & 0.0 \% & 19.4 \% \\ 26.6 \% & 18.2 \% & 38.7 \% \\ 61.7 \% & 81.8 \% & 41.9 \%\end{array}$

$84.6 \%$ of Cluster1 were quite close to the tourism development axis, with a midpoint around zero and some variation in both negative and positive values. Respondents were therefore labeled as supportive of nature conservation (Fig. 3). They comprised approximately $57.7 \%$ of the total sample. Between $65 \%$ and $73 \%$ of the respondents living in Ruka, Syötekylä, Sarajärvi, and downtown Kuusamo belonged to this group, compared to less than $50 \%$ of the respondents in northern Kuusamo and southern Kuusamo (Table 5). The proportion of respondents in Cluster1 decreased with increasing age. Between $66 \%$ and $77 \%$ of respondents with an intermediate or higher educational level belonged to Cluster1, whereas only $44 \%$ of those with an elementary school education fell into this category (Table 5). Less than 50\% of entrepreneurs and pensioners belonged to Cluster1, whereas the proportion was higher, between $67 \%$ and $81 \%$, for employees and for respondents from the other occupations, i.e., unemployed, housewife/husband, and student. Almost $70 \%$ of returnees and newcomers belonged to Cluster1, whereas the proportion of natives was less than $50 \%$ (Table 5). The proportion of respondents in Cluster 1 decreased with decreasing frequency of contact with tourists through work (Table 5). In addition, $81 \%$ of the respondents who reported that nature conservation 
Table 4. Dependency between the groups of respondents divided by clustering according to their opinions about nature conservation and tourism development (Chi-square analysis), $n=245-294$.

\begin{tabular}{llll}
\hline \hline Socioeconomic variable & $\chi^{2}$ & $d f$ & $p$ \\
\hline Residential area & 21.704 & 10 & 0.017 \\
Gender & 3.811 & 2 & n.s. \\
Age & 10.620 & 4 & 0.031 \\
Level of education & 21.966 & 4 & $<0.001$ \\
Primary occupation & 17.498 & 6 & 0.008 \\
Indigenousness & 13.603 & 4 & 0.009 \\
Frequency of contact with tourists through work & 14.650 & 4 & 0.005 \\
Income & 2.461 & 4 & n.s. \\
Land ownership & 4.549 & 2 & n.s. \\
Land donated to conservation & 3.469 & 2 & n.s. \\
Income from tourism & 4.553 & 4 & n.s. \\
Effects of nature conservation on household economy & 27.896 & 4 & $<0.001$ \\
& & & \\
\hline
\end{tabular}

had benefited their household economies and $63 \%$ of those who said that it had not belonged to Cluster1 (Table 5).

\section{Cluster2: Critical of nature conservation}

Cluster2 members, who comprised $30.5 \%$ of the respondents, were generally critical of nature conservation but quite neutral toward tourism development (Fig. 3). The proportion of respondents in Cluster2 was higher (more than 40\%) in northern Kuusamo and southern Kuusamo than in other residential areas. Also, more than a third of the respondents who were in the oldest age class, had an elementary school education, were entrepreneurs or pensioners, and were natives of the area belonged to Cluster2 (Table 5). More than half of the respondents who reported that nature conservation was a disadvantage for the household economy belonged to Cluster2 (Table 5).

\section{Cluster3: Critical of tourism development}

Cluster3 members were, on average, critical of tourism development but quite neutral toward nature conservation. Only $11.8 \%$ of the respondents belonged to this group. The proportion of members in other socioeconomic and demographic groups varied from 4.3 to $20.3 \%$ (Table 5). This cluster membership was best explained by the frequency of contact with tourists through work.

\section{DISCUSSION}

The majority of respondents $(57.7 \%)$ were classified as supportive of nature conservation and neutral to tourism development, which may indicate a coexistent relationship according to the classification by Budowski (1976). However, the numbers of respondents in other categories were also relatively large, indicating that local 
Table 5. Frequencies of clusters (percentages in parentheses) in terms of the socioeconomic and demographic characteristics of the respondents.

\begin{tabular}{|c|c|c|c|}
\hline $\begin{array}{l}\text { Socioeconomic/demographic } \\
\text { characteristic }\end{array}$ & $\begin{array}{l}\text { Supportive } \\
\text { of nature } \\
\text { conservation }\end{array}$ & $\begin{array}{l}\text { Critical of } \\
\text { nature conservation }\end{array}$ & $\begin{array}{l}\text { Critical of tourism } \\
\text { development }\end{array}$ \\
\hline \multicolumn{4}{|l|}{ Residential area } \\
\hline Ruka & $16(72.7 \%)$ & $5(22.7 \%)$ & $1(4.5 \%)$ \\
\hline Syötekylä & $20(64.5 \%)$ & $6(19.4 \%)$ & $5(16.1 \%)$ \\
\hline Northern Kuusamo & $25(46.3 \%)$ & $23(42.6 \%)$ & $6(11.1 \%)$ \\
\hline Southern Kuusamo & $23(41.1 \%)$ & $23(41.4 \%)$ & $10(17.9 \%)$ \\
\hline Sarajärvi & $27(73.0 \%)$ & $5(13.5 \%)$ & $5(13.5 \%)$ \\
\hline Downtown Kuusamo & $40(64.5 \%)$ & $18(29.0 \%)$ & $4(6.5 \%)$ \\
\hline \multicolumn{4}{|l|}{ Age } \\
\hline $20-44 \mathrm{yr}$ & $46(65.7 \%)$ & $18(25.7 \%)$ & $6(8.6 \%)$ \\
\hline $45-64 \mathrm{yr}$ & $71(59.2 \%)$ & $31(25.8 \%)$ & $18(15.0 \%)$ \\
\hline $65-90 \mathrm{yr}$ & $32(46.4 \%)$ & $31(44.9 \%)$ & $6(8.7 \%)$ \\
\hline \multicolumn{4}{|l|}{ Level of education } \\
\hline Higher education & $47(77.0 \%)$ & $10(16.4 \%)$ & $4(6.6 \%)$ \\
\hline High school & $48(65.8 \%)$ & $16(21.9 \%)$ & $9(12.3 \%)$ \\
\hline Elementary school & $53(43.8 \%)$ & $51(42.1 \%)$ & $17(14.0 \%)$ \\
\hline \multicolumn{4}{|l|}{ Primary occupation } \\
\hline Entrepreneur & $22(46.8 \%)$ & $17(36.2 \%)$ & $8(17.0 \%)$ \\
\hline Employee & $58(66.7 \%)$ & $23(26.4 \%)$ & $6(6.9 \%)$ \\
\hline Pensioner & $45(47.4 \%)$ & $36(37.9 \%)$ & $14(14.7 \%)$ \\
\hline Other & $25(80.6 \%)$ & $3(9.7 \%)$ & $3(9.7 \%)$ \\
\hline \multicolumn{4}{|l|}{ Indigenousness } \\
\hline Native & $56(45.9 \%)$ & $49(40.2 \%)$ & $17(13.9 \%)$ \\
\hline Returnee & $45(67.2 \%)$ & $14(20.9 \%)$ & $8(11.9 \%)$ \\
\hline
\end{tabular}


Newcomer

Frequency of contact with tourists through work

Frequently

Infrequently

Not at all

The effects of nature conservation on household economy

Disadvantage

$11(24.4 \%)$

No effect

$118(62.5 \%)$

$17(81.0 \%)$
$31(66.0 \%)$

$51(63.0 \%)$

$62(50.4 \%)$
Benefit

$16(22.9 \%)$

$6(8.6 \%)$

$2(4.3 \%)$

$4(4.9 \%)$

$25(20.3 \%)$
$25(55.6 \%)$

$53(28.0 \%)$

$2(9.5 \%)$
$9(20.0 \%)$

$18(9.5 \%)$

$2(9.5 \%)$ communities are heterogeneous (Ryan and Montgomery 1994). Personal characteristics such as age and level of education affected the opinions of the respondents, unlike factors related to income and land ownership.

Opinions were generally strongly affected by the socioeconomic background of the respondents (Brougham and Butler 1981, Kinzig et al. 2005). However, because there was some overlap of the socioeconomic characteristics of the residents of conservation areas, tourist resorts, and downtown Kuusamo, we did not find clear differences in their opinions. Age and contact with tourists through work were the only factors that were consistently different. The residents living close to conservation areas were, on average, older than the residents of the other areas. They also had fewer contacts with tourists at work than did the inhabitants of tourism areas and downtown Kuusamo. Compared to young and middle-aged respondents, more older respondents were critical of nature conservation but neutral toward tourism development. A similar trend has also been shown in earlier studies (Haralambopoulos and Pizam 1996, Fredline and Faulkner 2000), although it has also been suggested that older people have more positive opinions (Brougham and Butler 1981) or that opinions are independent of age (Ryan and Montgomery 1994, Tomljenovic and Falkner 2000). The negative opinions of the older respondents in our study might be a consequence of their personal experience with the conservation process and tourism near their homes or fear that conservation may negatively affect their standard of living.

Respondents living in the Ruka tourist resort and downtown Kuusamo had on average a higher level of education and a higher level of income compared to respondents from other areas, which might have been a reason for their higher level of acceptance of nature conservation and tourism (Heinen 1993). However, not all studies have shown a relationship between level of education and opinions about tourism (Weaver and Lawton 2001). Ruka was the only area in which most residents were either newcomers or returnees, whereas natives were dominant in the other areas. Compared to natives, respondents born outside of the residential area in which they were living were more positive in their opinions about nature conservation and tended to be neutral toward tourism development. The longer the respondents had lived in the community, the more negative they were toward tourists and tourism (Broughan and Butler 1981, Liu and Var 1986, Allen et al. 1988). Lifelong residents were found to be more susceptible to the impacts of tourism (Sheldon and Var 1984). On the other hand, newer residents can also be negative toward increasing tourism (Goudy 1977, Ayers and Potter 1989). 
Compared with residents who had no contact with tourists, particularly in conservation areas, more of the respondents who had frequent or infrequent contacts with tourists through work were supportive of nature conservation but neutral to tourism development. Residents working in the tourism industry or dependent on tourism had more positive opinions about tourism than those who were not employed in the tourism sector (Pizam 1978, Murphy 1985, Ryan and Montgomery 1994, Cottrell et al. 2007), because contact with tourists is often connected with earnings from tourism and the perception that tourism improves the level of employment, local services, and income. We could not find any residents of tourist resorts who supported both nature conservation and tourism development, which might be due, at least in part, to the limited number of respondents from tourist centers. Earlier studies have shown that people living near tourist resorts have more positive opinions of tourism than those who live farther from tourism centers (Belisle and Hoy 1980). Nevertheless, seasonal unemployment and other negative effects of tourism on the community may make residents reluctant to invest in tourism in their own areas (Winter-Ebmer and Zweimüller 1999).

Almost all respondents of northern Kuusamo and southern Kuusamo owned land, and many had donated land for conservation, whereas most respondents from Sarajärvi did not own land. In spite of that, we did not find any statistically significant association between land ownership and opinions about nature conservation or tourism development, whereas respondents living in northern Kuusamo and southern Kuusamo were more negative toward nature conservation than in Sarajärvi. Thus, negative opinions of conservation might be related at least partly to land ownership and donation to conservation. Moreover, there was a difficult and controversial conservation process in southern Kuusamo in the 1990s, whereas in Sarajärvi the initiative for conservation came from the local community. Most of the respondents who reported that nature conservation had a positive or neutral effect on their household economies were positive toward nature conservation. Similarly, more than half of the respondents who felt that nature conservation had harmful effects on their economy had negative opinions of nature conservation. In general, most of the negative attitudes toward nature conservation were influenced by: (1) the lack of involvement of local people in the foundation and management of protected areas, (2) the lack of perceived benefits from protected areas, and (3) interactions between local people and conservation administrators (Fiallo and Jacobson 1995).

The most critical opinions of nature conservation were expressed by local residents who lived close to conservation areas, because they regarded conservation as something that might reduce employment and incomes. Local communities, especially those living in and close to protected areas, often have important and long-standing relationships with their neighborhoods and may also be dependent on local resources for their livelihoods (Trakolis 2001). In addition, there may be situations in which nature conservation can limit tourism development, although Budowski (1976) did not include this possibility in his framework. This kind of conflict may occur, for example, in extremely sensitive areas in which the number of visitors is limited or from which they are excluded entirely. There are studies that show that income from tourism can compensate for the benefits and revenues previously derived from natural resources (e.g., Kiss 2004). However, there are also situations in which income from tourism does not compensate for previous benefits. For example, Bookbinder et al. (1998) reported that the economic effects of ecotourism on the villagers living near Royal Chitwan National Park, Nepal, were minimal and limited to those living in close proximity to the main entrance to the park.

\section{CONCLUSION}

According to our survey, the responses of local inhabitants to questions about nature conservation and nature-based tourism development depended to a large extent on their socio-demographic backgrounds and values. When local stakeholders and the community had an opportunity to participate in the planning process from the very beginning, they had more positive perceptions of and opinions about the development of their residential areas than residents who did not participate in the planning process. At present, the community-based, i.e., bottom-up, approach is widely used in Finland, whereas, when first national parks were established in our study area, a top-down approach to planning was prevalent.

Our results show that people in the developed world can have concerns and complaints about nature 
conservation and tourism development similar to those of the inhabitants of developing countries. The negative opinions of local residents may be related to the planning tradition of the region. As commonly happens in developing countries, nature-based tourism may not be sustainable if it is imposed by top-down regimes (e.g., Tosun 1999, 2000). The negative opinions and insufficient commitment of local people to the planning process may therefore hinder nature conservation and tourism development in the area. Objective information about the possible positive impacts of development on, e.g., employment and incomes might encourage local residents to become more committed and less critical.

Consideration of the local residents should be a crucial component of tourism planning, but there is still the problem of how to get all the stakeholders involved. Our survey indicates that demographic data and information on the level of education and income helps to identify the types of opinion groups that might be present in the local community. Tracking possible opinion groups might help to focus the discussion on those risks and benefits that most closely affect the residents. The sharing of ideas among different stakeholders over an extended period can lead to a deeper understanding of the issues and should result in more legitimate and sustainable policies.

Qualitative methods such as thematic interviews and focus groups can deepen the knowledge of stakeholder attitudes and the factors that affect them. In addition to the quantitative methods used in the present study, qualitative investigations are necessary for local and regional tourism planning and management, because they provide supplementary tools and knowledge that can be used to assess the socioeconomic sustainability of nature conservation and tourism development in a local context.

Responses to this article can be read online at: http://www.ecologyandsociety.org/voll3/iss 1/art8/responses/

\section{Acknowledgments:}

The authors especially thank the respondents who kindly took part in the survey and thus participated in this research project. We also thank the staff of Oulanka Research Station and Metsähallitus for practical help. We would like to thank J. Aarnio, $M$. Hovi, I. Kinnunen, M. Tanskanen, M. Tapaninen, and S. Vanhamäki for their useful comments during many phases of the research, and special thanks to Stuart Cottrell and two anonymous referees for valuable comments on the manuscript. I would like to thank Aaron Bergdahl and Andrew Baker for revising the English language. We received funding from EU, ESF, the MajandTor Nessling Foundation, the Societas pro Fauna et Flora Fennica, the environmental graduate school (University of Oulu), the Finnish Society of Forest Science, and the Kuopio Naturalists' Society.

\section{LITERATURE CITED}

Aarnio, J. 2001. Maankäytön historiaa Syötteen alueella. Metsähallituksen luonnonsuojelujulkaisuja Sarja A-133:73.

Allen, L. R., P. T. Long, R. Perdue, and S. Kieselbach. 1988. The impact of tourism development on residents' perception of community life. Journal of Travel Research 27:16-21.

Ayers, J. S., and H. R. Potter. 1989. Attitudes towards community change: a comparison between rural leaders and residents. Journal of the Community Development Society 20:1-18.

Belisle, F. J., and D. R. Hoy. 1980. The perceived impact of tourism by residents: a case study in Santa Marta, Colombia. Annals of Tourism Research 7:83-101.

Boo, E. 1990. Ecotourism: the potential and pitfalls. World Wildlife Fund, Baltimore, Maryland, USA.

Bookbinder, M. P., E. Dinerstein, A. Rijal, H. Cauley, and A. Rajouria. 1998. Ecotourism's support of biodiversity conservation. Conservation Biology 12:1399-1404.

Brougham, J. E., and R. W. Butler. 1981. A segmentation analysis of residents' attitudes to the social impact of tourism. Annals of Tourism Research 8:569-589.

Buckley, R. C. 1994. A framework for ecotourism. Annals of Tourism Research 21:661-665. 
Budowski, G. 1976. Tourism and environmental conservation: conflict, coexistence, or symbiosis? Environmental Conservation 3:27-31.

Cottrell, S. P., J. J. Vaske, F. Shen, and P. Ritter. 2007. Resident perceptions of sustainable tourism in Chongdugou, China. Society and Natural Resources 20(6):511-525.

Eagles, P. F. J., S. F. McCool, and C. D. Haynes. 2002. Sustainable tourism in protected areas; guidelines for planning and management. World Conservation Union (IUCN). Available online at: http://turismo-sostenible.rds.hn/documet/iniciativas/ tourismguidelines.pdf.

Ecotourism Society. 1993. Ecotourism: a guide for planners and managers. Ecotourism Society, North Bennington, Vermont, USA.

Fiallo, E. A., and S. K. Jacobson. 1995. Local communities and protected areas: attitudes of rural residents towards conservation and Machalilla National Park, Ecuador. Environmental Conservation 22:241-249.

Finnish Tourist Board. 2005. Matkailukohteiden kävijämäärät 2004. MEK E:49. Matkailun edistämiskeskus, Helsinki, Finland.

Forbes, B. C., C. Monz, and A. Tolvanen. 2004. Tourism ecological impacts in terrestrial polar ecosystems. Pages 155-170 in R. Buckley, editor. Environmental impacts of ecotourism. CAB International, Cambridge, UK.

Fredline, E., and B. Faulkner. 2000. Host community reactions: a cluster analysis. Annals of Tourism Research 27:763-784.

Goudy, W. J. 1977. Evaluations of local attributes and community satisfaction in small towns. Rural Sociology 42:371-382.

Hair, J., R. Anderson, R. Tatham, and W. Black. 1995. Multivariate data analysis with readings. Fourth edition. Prentice Hall, Englewood Cliffs, New Jersey, USA.

Haralambopoulos, N., and A. Pizam. 1996. Perceived impacts of tourism: the case of Samos. Annals of Tourism Research 23:503-526.

Heinen, J. T. 1993. Park-people relations in Kosi
Tappu Wildlife Reserve, Nepal: a socio-economic analysis. Environmental Conservation 20:25-34.

Helle, T., and M. Särkelä. 1993. The effects of outdoor recreation on range use by semidomesticated reindeer. Scandinavian Journal of Forest Research 8:123-133.

Hunter, C., and Green, H. 1995. Tourism and the environment: a sustainable relationship? Routledge, London, UK.

Kim, J. O., and C. W. Muller. 1978. Introduction to factor analysis: what it is and how to do it. Quantitative Applications in the Social Sciences No. 9. Sage, Beverly Hills, California, USA.

Kinzig, A. P., P. Warren, C. Martin, D. Hope, and M. Katti. 2005. The effects of human socioeconomic status and cultural characteristics on urban patterns of biodiversity. Ecology and Society 10(1):23. [online] URL: http://www.ecologyandsoc iety.org/vol10/iss 1/art23/.

Kiss, A. 2004. Is community-based ecotourism a good use of biodiversity conservation funds? TREE 19:232-237.

Liu, J. C., and T. Var. 1986. Residents' attitudes towards tourism impacts in Hawaii. Annals of Tourism Research 13:193-214.

Metsähallitus. 2006. Metsähallituksen luontopalvelut Vuosikertomus 2005. Available online at: http://ww w.metsa.fi/binary.aspx?Section=2082\&Item=5061

Muphy, P. E. 1985. Tourism: a community approach. Methuen, New York, New York, USA.

Parks, P. J., G. Bostedt, and B. Kriström. 2002. An integrated system for management and policy analysis. Environmental and Resource Economics 21:203-220.

Pearce, P. L., G. Moscardo, and G. F. Ross. 1996. Tourism community relationships. Pergamon, Oxford, UK.

Pizam, A. 1978. Tourism's impacts: the social costs to the destination as perceived by its residents. Journal of Travel Research 16:8-12.

Ryan, C., and D. Montgomery. 1994. Case study: 
the attitudes of Bakewell residents to tourism and issues in community responsive tourism. Tourism Management 15:358-369.

Rydin, Y., and M. Pennington. 2000. Public participation and local environmental planning: the collective action problem and the potential of social capital. Local Environment 5:153-169.

Saarinen, J. 2006. Traditions of sustainability in tourism studies. Annals of Tourism Research 33:1121-1140.

Saastamoinen, O., L. Loven, and T. Sievänen. 2000. Nature-based tourism in forested NorthEurope: the case of Finland. Pages 7-18 in L. Loven, editor. Responsible nature tourism. Metsäntutkimuslaitoksen tiedonantoja 792. Finnish Forest Research Institute, Helsinki, Finland.

Sekhar, N. U. 2003. Local people's attitude towards conservation and wildlife tourism around Sariska Tiger Reserve, India. Journal of Environmental Management 69:339-347.

Sheldon, P., and T. Var. 1984. Residents' attitudes toward tourism in North Wales. Tourism Management 5:40-47.

Shortt, G. 1994. Attitudes of tourism planners: implications for human resource development. Tourism Management 15:444-450.

SPSS. 2003. SPSS base 12.0 user's guide. SPSS, Chicago, Illinois, USA.

Statistics Finland. 2004. Suomi CD (Finland CD). Statistics Finland, Helsinki, Finland.

Tomljenovic, R., and B. Faulkner. 2000. Tourism and older residents in a sunbelt resort. Annals of Tourism Research 27:93-114.

Tosun, C. 1999. Towards a typology of community participation in the tourism development process. International Journal of Tourism and Hospitality 10:113-134.

Tosun, C. 2000. Limits to community participation in the tourism development process in developing countries. Tourism Management 21:613-633.

Tosun, C. 2006. Expected nature of community participation in tourism development. Tourism
Management 27:493-504.

Trakolis, D. 2001. Local people's perceptions of planning and management issues in Prespes Lakes National Park, Greece. Journal of Environmental Management 61:227-241.

UNEP. 2007. User's manual on the CBD guidelines on biodiversity and tourism development. Available online at: http://www.cbd.int/doc/programmes/socioeco/tourism/tourism-manual-en.pdf.

Vuoristo, K.-V., and N. Vesterinen. 2001. Lumen ja Suven maa. WSOY, Helsinki, Finland.

Vuoristo, K.-V. 2002. Regional and structural patterns of tourism in Finland. Fennia 180:251-259.

Weaver, D. B., and L. J. Lawton. 2001. Residents' perceptions in the urban-rural fringe. Annals of Tourism Research 28:439-458.

Western, D., and R. M. Wright. 1994. The background to community-based conservation. Pages 1-12 in D. Western, R. M. Wright, and S. C. Strum, editors. Natural connections: perspectives in community-based conservation. Island Press, Washington D.C., USA.

Winter-Ebmer, R., and J. Zweimüller. 1999. Do immigrants displace young native workers: the Austrian experience. Journal of Population Economics 12:327-340. 
Appendix 1. Profile of survey respondents by proportion (\%) of all respondents, statistics of respondents according to Statistics Finland in parenthesis. Total number of respondents was 295 and total number of inhabitants was 27069.

Please click here to download file 'appendix1.pdf'. 